\title{
Method of Design of Land use of Local Eco-Network Structural Elements
}

\author{
Tretiak A.M., Hunko L.A., Medynska N.V., Hetmanchyk I.P
}

\begin{abstract}
There are presented the theoretical and methodological principles of the formation of eco-network in Ukraine for the purpose of the development of the environment-oriented land use. The method of the land planning of the land use of eco-network structural elements on the territory of village council that uncovers the main stages of the design of land use. Besides, there are mentioned the criteria of territory delimitation to include it to the eco-network structural elements and the main approaches to the design of land use.
\end{abstract}

Keywords - land use, ecological networks, land planning, the key area, landscapes

\section{INTRODUCTION}

Human society uses a huge amount of natural resources at the current level of science and technology development: not only minerals, but wildlife. Besides, it uses nature landscapes for the recreational and aesthetic purposes. That is why the preservation and careful attitude towards nature is high-priority task for all countries. One of the most important steps to the solving of this problem is the formation of land use nature conservation by creating especially secured natural territories, which promote the preservation and restoration of valuable and unique natural objects and plots, and their studying, too.

Therefore, at the end of 20th - at the beginning of $21 \mathrm{st}$ century the need of the creation of continuous network of nature conservation objects became definitely clear [1].

Under such circumstances, the problems of the formation of ecological network of Ukraine become more relevant.

\section{ANALYSIS OF THE RECENT RESEARCHES AND PUBLICATIONS.}

Attention to the problems of the formation of ecological network in the recent years has increased. Significant contribution to the development of the theoretical, methodical and practical aspects of the usage and land conservation of nature reserves was made by: D. Dobriak, Y. Dorosh, O. Kanash, A. Martyn, Ya. Movchan, O. Novotorov,

Revised Manuscript Received on 06 November, 2019.

Anton Tretiak, Director of the Institute of Economics and Ecology of Nature Management, State Ecological Academy of Postgraduate Education and Management, Kyiv, Ukraine. (E-mail: nnieco@ukr.net)

Liudmyla Hunko, Associate Professor at the Department of land-use planning, PhD candidate of Economy, National University of Life and Environmental Sciences of Ukraine, Kyiv, Ukraine.

(E-mail: liudmyla_g@ukr.net)

Nataliia Medynska, Associate Professor at the Department of land cadastre, PhD candidate of Economy, National University of Life and Environmental Sciences of Ukraine, Kyiv, Ukraine.

(E-mail: natazv@ukr.net)

Ivanna Hetmanchik, Separated subdivision of NULES "Boiarka College of Ecology and Natural Resources", Kyiv, Ukraine.

(E-mail: 170975ivanna@ukr.net)
A. Sokhnych, A. Tretiak and others. However, there are approaches that are not worked out for the formation of the structural elements of local eco-network.

\section{METHODOLOGY OF RESEARCH AND MATERIALS}

The methodology of the developed land-use design projects of the produced ecologically clean ecological directions is elaborated, and this subject is investigated by methodological and applied aspects based on the ecological environmental impact of Ukraine. The study used general scientific and special methods, namely: monographs - for the research of researchers who studied problems, studied problems; statistical - to use relevant statistics, land data; economic analysis - for effective land use efficiency.

\section{DISCUSSION AND RESULTS}

In the system of land management of any country, the planning of use and protection of lands and other natural resources is the most important function that determines the possibilities of environment conservancy. It is the way of realization of land and ecological politics of states and the concordance of national, regional and local interests in terms of rational land use and other natural recourses and their preservation.

Nature Reserve Fund of Ukraine takes a little more than $6 \%$ of the territory of Ukraine. Herewith, the percentage of natural reservations is $6,4 \%$, biosphere reservations $-9,1 \%$ and national parks - 23,9\% of this Fund [2].

The formation of environmental land use, under the conditions of the new land relationships is made on the basis of the eco-economic value of natural resources and biodiversity, natural landscapes that are not much changed by anthropogenic activities or in the result of the reconstruction of natural and economic systems of land use, identification of property rights to land and other natural resources etc. by the method of planning.

According to Art. 15 of the Law of Ukraine "On ecological network of Ukraine", the planning of eco-network is made by the development of regional schemes of the formation of region eco-network, as well as local schemes of the formation of district, settlement and other territories eco-network [3].

By taking into account that the local schemes of eco-network are not related to the planning documentation and in the existing planning documentation eco-network planning cannot made, we suggest to develop independent 
planning projects in terms of the designing of the eco-network components in the light of the territories of village councils [4].

If during the planning of the eco-network components at the national and regional levels there are used spatial and landscape planning together, then at the local level the territorial planning has greater advantage [5].

The design of land use of structural elements of eco-network on the territory of village council begins from the eco-landscape microzoning of the territory of village council that is conducted during the preparation works of the land survey project planning and ends at the formation of ecologically homogeneous areas to which the system of components of the eco-network, environmental measures through the territorial environmental restrictions (burdens) in land use and other natural resources is connected.

Let's consider the method of planning of the territories of the structural elements of the local eco-network at the example of Sokil village council territory, Kamianets-Podilskyi district, Khmelnytsk region.

Detailed and current methods and standards for the planning projects development in terms of the planning of the territory of structural elements of local eco-network currently do not exist. That is why let's uncover the problems and approaches to the planning.

As the data shows (Table- I), the land use of structural elements of eco-network (including key areas) is absent on the territory of Sokil village council.

Table- I: Characteristic of the existing land distribution within the territory of Sokil village council

\begin{tabular}{|c|c|c|c|}
\hline \multirow{2}{*}{ № } & \multirow{2}{*}{ Name of land } & \multicolumn{2}{|c|}{ As at 01.01.2015 } \\
\hline & & $h a$ & $\%$ \\
\hline 1 & Tillage & 1954.2 & 59.7 \\
\hline 2 & Perennial plantings & 10.6 & 0.3 \\
\hline 3 & Hayfields & 201.0 & 6.1 \\
\hline \multirow[t]{2}{*}{4} & Pastures & 157.5 & 4.8 \\
\hline & Agricultural land, total & 2323.3 & 70.9 \\
\hline 6 & Under ways and purlines & 43.8 & 1.3 \\
\hline \multirow[t]{2}{*}{7} & $\begin{array}{l}\text { Under household buildings } \\
\text { and courtyards }\end{array}$ & 19.4 & 0.6 \\
\hline & $\begin{array}{l}\text { Total amount of } \\
\text { agricultural lands }\end{array}$ & 2386.5 & 72.9 \\
\hline 9 & Forests and forested area & 199.1 & 6.1 \\
\hline 9.1 & wooded lands & 175.4 & 5.4 \\
\hline 9.2 & where: forest shelter belts & 11.1 & 0.3 \\
\hline 10 & Built-up lands & 85.6 & 2.6 \\
\hline 11 & Open with slight vegetation & 73.9 & 2.3 \\
\hline 12 & Under water & 529.6 & 16.2 \\
\hline \multirow[t]{4}{*}{12.1} & $\begin{array}{l}\text { including artificial } \\
\text { reservoir }\end{array}$ & 529.2 & 16.2 \\
\hline & Total & 3274.7 & 100.0 \\
\hline & $\begin{array}{l}\text { from the total area of } \\
\text { structural elements of } \\
\text { eco-network }\end{array}$ & - & - \\
\hline & including key areas & - & - \\
\hline
\end{tabular}

* source: calculated according to the data of the form of 2nd-zem StateGeoCadastre of Ukraine
There is extremely high level of the life area development on the territory of Sokil village council: more than $62 \%$ of its territory was implicated to the practical use. Only 1234.9 ha $(37.7 \%)$ of eco-stable lands where the lands of natural state (rivers and open lands with small vegetation) are absent.

According to the data of Project of the organization of NNP territory "Podilski Tovtry", on the territory of Sokil village council there are some rare kinds of plants and animals that are listed in the Red Book and are of regional meaning [1]. However, the territories of the sites of flora species distribution as key, within the territory of Sokil village council on the regional scheme of the eco-network are not specified, at the same time the sites of distribution of valuable plant aggregations were identified during the project development of the organization of the territory of the NNP "Podilski Tovtry". When solving the problem of natural land development for the creation of new sections of the eco-network, the problem arises of determining the requirements for setting the spatial parameters of such areas by area and location in relation to other natural and anthropogenic territories.

As the process of transformation of land designation from anthropogenic to natural land has to take place according to the procedures stipulated by the land legislation, the spatial parameters of the future plot og land are determined by its boundaries in the land management system. The selection of plots for naturalization ин the subject of the formation of the eco-network is the result of an assessment of the potential suitable for this territory and the possibility of its release (full or partial) from the existing economic load.

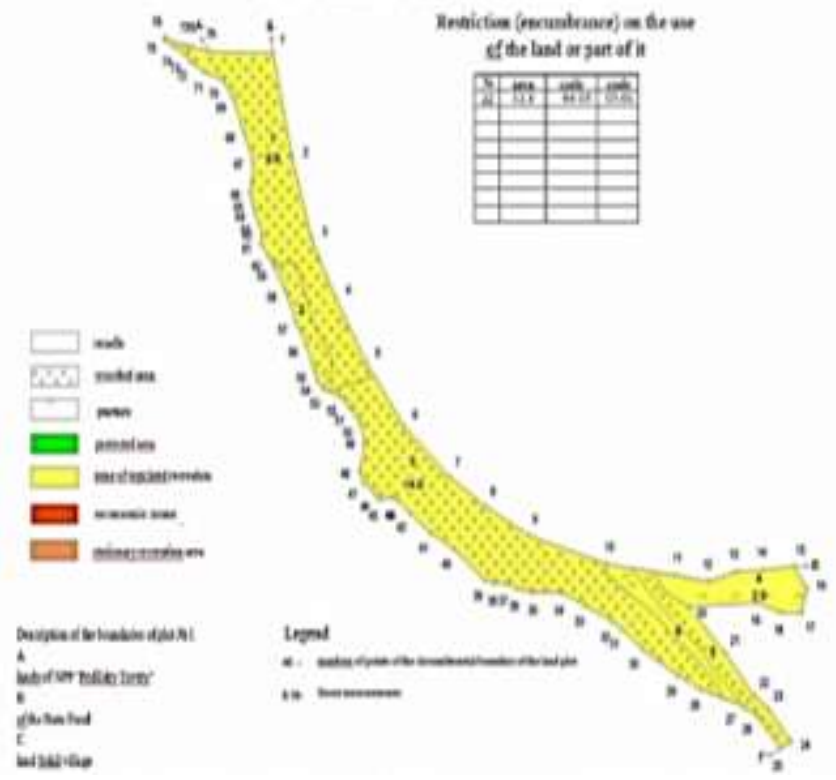

Fig.1. Plan of plots of land of constant use of NNP "Podilski Tovtry" on the territory of Sokil village council, Kamianets-Podilskyi district, Khmelnytsk region 
Thus, according to the project, land with valuable species of plants listed in the Red Book of Ukraine, which are not mentioned on the regional scheme of the ecological network, should be included to the key areas of the ecological network. All these plots of land are in constant use of the Podilski Tovtry National Park (Fig. 1).

Hence, at the local level, the design of boundaries and the regime of land use of structural elements of the eco-network of Ukraine should be carried out by planning projects in the scale of $1: 10,000$ or 1:5,000 using the soil-land management method.

The planning project in terms of the organization of the territory of structural elements of eco-network will give the possibility to provide the compliance with the restricted regime of anthropogenic activity on the proper territories.

By analyzing the topographic features of Sokil village council and the soil cover, it is possible to identify connective territories and buffer areas. Forested areas and pastures adjoins to the key areas. It is recommended to classify them to the connective territories which after the connection will provide the connections between the key areas ans the wholeness of eco-network and they will facilitate in the preservation of the landscape diversity. Buffer zones should be highlighted around the key areas on highly-eroded soils that will protect these lands from the adverse effects of economic activity.

Around the location of the rare plants (plot № 20, Fig. 2), a buffer zone, represented by forest lands of 4.43 ha, should be put somewhere. On highly-eroded and degraded soils (the code of agricultural group $50 \mathrm{~d}, 57 \mathrm{e}$ ), it is necessary to establish a restoration area in which priority measures will be taken to restore the original natural state. They are subject to conservation and their area is 13.91 ha. On others - to carry out remedial actions. The area of these lands is 25.60 ha. Some lands of recreative territories can be included to the key area or the connective territory after taking appropriate measures (grassland and forest planting). It is recommended to include the land plots that will take 15.54 ha (forest lands and lands under water) between the locations of rare plants (plots № 20 and 21) to the connective territory (eco-corridor) of eco-network.

It is known that environmentally sustainable lands (forests, marshes of natural origin, natural meadows) create a favorable ecological environment around them and have a positive effect on the environment, its flora and fauna and vice versa. To establish the boundaries of the buffer zone, which provides protection of key areas from negative anthropogenic impact (the effects of external negative factors and optimization of certain forms of management), it is possible to determine the boundary distance of the buffer zone, namely the width of the favorable ecological zone of the buffer zone.

In the process of land planning such calculations should be made on all lands of the buffer zones and to plat on the planned basis the boundaries of ecologically stabilizing territories.

The boundaries of the buffer zone is plated on the plan (Fig. 3).

The proposed change of the land use regime caused the corresponding actions for their transformation (Table II). In particular, croplands on the area of 123.25 ha is foreseen to be transferred to grassland planting (conservation).

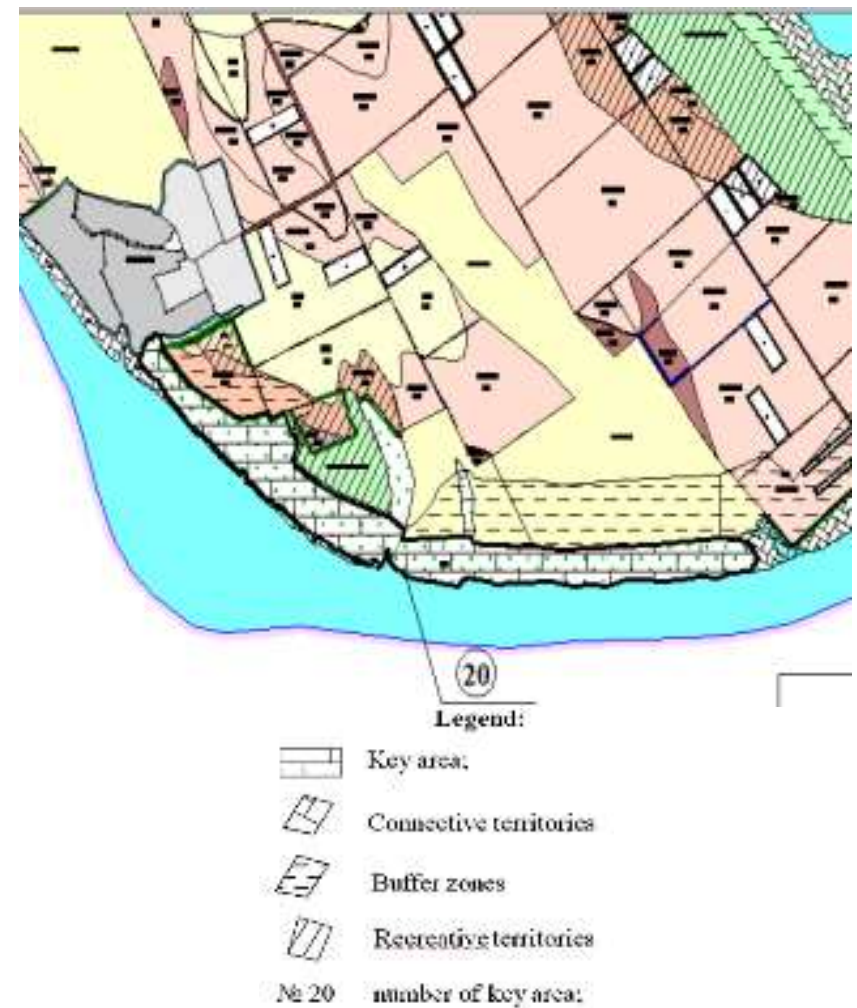

Fig. 2. The fragment of the project of structural elements of the eco-network within the territory of Sokil village council

Table- II: Explication of transformation of lands within the territory of Sokil village council

\begin{tabular}{|c|c|c|c|c|c|}
\hline$\stackrel{91}{2}$ & 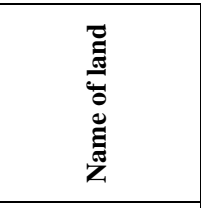 & 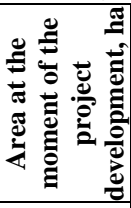 & 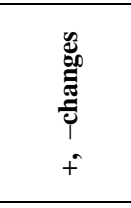 & 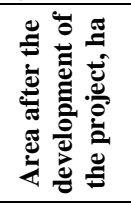 & 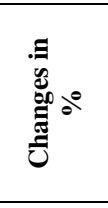 \\
\hline 1 & Tillage & 1954.2 & -123.25 & 1830.95 & -6.31 \\
\hline 2 & $\begin{array}{l}\text { Perennial } \\
\text { plantings }\end{array}$ & 10.6 & - & 10.60 & - \\
\hline 3 & Hayfields & 201.0 & +123.25 & 324.25 & +61.32 \\
\hline \multirow[t]{2}{*}{4} & Pastures & 157.5 & - & 157.5 & - \\
\hline & $\begin{array}{l}\text { Agricultural } \\
\text { land, total }\end{array}$ & 2323.3 & - & 2323.3 & - \\
\hline 5 & $\begin{array}{l}\text { Under ways } \\
\text { and purlines }\end{array}$ & 43.8 & - & 43.8 & - \\
\hline 6 & $\begin{array}{l}\text { Under } \\
\text { household } \\
\text { buildings } \\
\text { and } \\
\text { courtyards } \\
\end{array}$ & 19.4 & - & 19.4 & - \\
\hline & $\begin{array}{l}\text { Total } \\
\text { amount of } \\
\text { agricultural } \\
\text { lands }\end{array}$ & 2386.5 & - & 2386.5 & - \\
\hline
\end{tabular}


Table- II: Explication of transformation of lands within the territory of Sokil village council

\begin{tabular}{|c|c|c|c|c|c|}
\hline 品 & 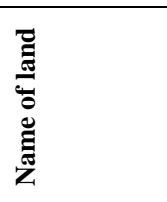 & 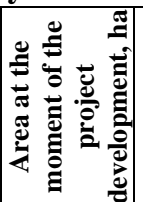 & 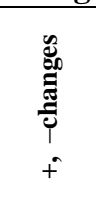 & 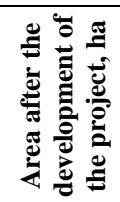 & 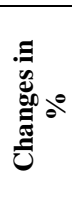 \\
\hline 7.1 & $\begin{array}{l}\text { wooded } \\
\text { lands }\end{array}$ & 175.4 & - & 175.4 & - \\
\hline 7.2 & $\begin{array}{l}\text { where } \\
\text { forest } \\
\text { shelter } \\
\text { belts }\end{array}$ & 11.1 & - & 11.1 & - \\
\hline 8 & $\begin{array}{l}\text { Built-up } \\
\text { lands }\end{array}$ & 85.6 & - & 85.6 & - \\
\hline 9 & $\begin{array}{l}\text { Open with } \\
\text { slight } \\
\text { vegetation }\end{array}$ & 73.9 & - & 73.9 & - \\
\hline 10 & $\begin{array}{l}\text { Under } \\
\text { water }\end{array}$ & 529.6 & - & 529.6 & - \\
\hline \multirow[t]{2}{*}{10.1} & $\begin{array}{l}\text { including } \\
\text { artificial } \\
\text { reservoir }\end{array}$ & 529.2 & - & 529.2 & - \\
\hline & Total & 3274.7 & 100.0 & 3274.7 & \\
\hline
\end{tabular}

To establish the boundaries of the buffer zone, which provides protection of key areas from negative anthropogenic impact, it is possible to determine the boundary distance of the buffer zone, namely the width of the favorable ecological zone of the buffer zone in relation to the key area [6].

Considering that the land use of the territory of Sokil village council is located on the territory of Podilsky Tovtry
National Nature Park, which belongs to the category of lands of the nature reserve fund and which is divided according to functional zoning for the preserved area, territories of regulated and stationary recreation and economic areas, the planning of the regime of land use of structural elements of eco-network should be made with these factors in mind.

We offer to differentiate the use of land and other natural resources within the structural elements of the eco-network, taking into account the protected zone, zones of regulated and stationary recreation and economic zone on the territory of Sokil village council, in accordance with the functional zoning of NNP Podilski Tovtry. Besides, it is taken into account that the land use of the protected area of the park fully belongs to the key area of eco-network. At the same time, valuable vegetation and fauna are included in the Red Book of Ukraine on the territory of Sokil village council, and these areas of land do not belong to the protected area of the park. Accordingly, we included these land plots (with numbers $18,19,20,21$ ) in the key territory of the ecological network.

The project allocation of land within the structural elements of the eco-network on the territory of Sokil village council is given in Table- III.

The area of land within the structural elements of the eco-network differs from the area of land within as the protected area of NNP Podilsky Tovtry, as in the whole park. This is due to both legislative conflicts of laws of Ukraine "On the Nature Reserve Fund of Ukraine" [8] and "On the Ecological Network of Ukraine" [3], as well as different methodological approaches (in the European Union and Ukraine) to the planning of the eco-network.

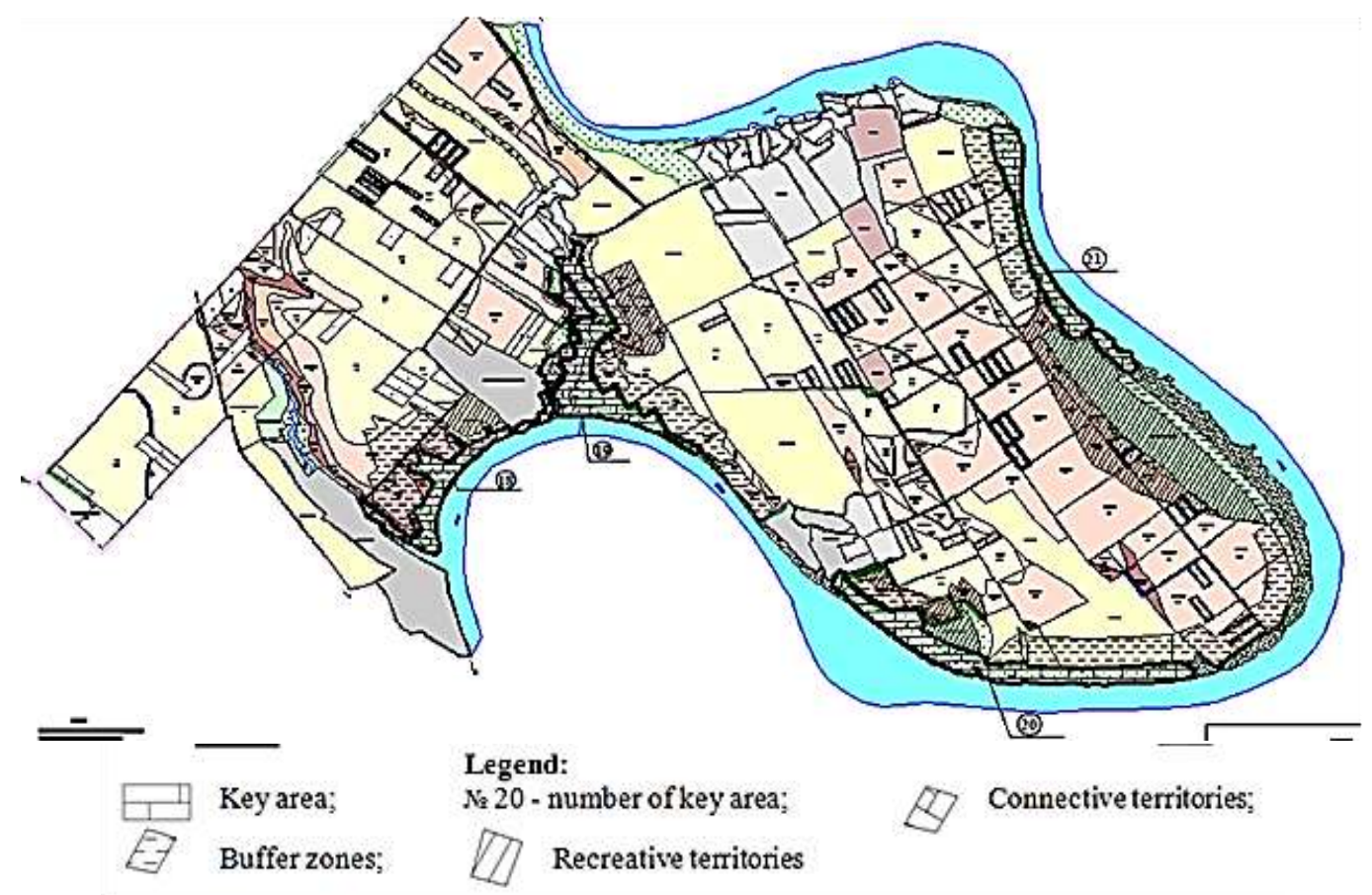

Fig. 3. Project plan of structural elements of the eco-network within the territory of Sokil village council, Kamyanets-Podilskyi district, Khmelnytskyi region 
Table- III: The project allocation of land within the structural elements of the eco-network on the territory of Sokil village council [7]

\begin{tabular}{|c|c|c|c|c|c|c|}
\hline \multirow[b]{2}{*}{ 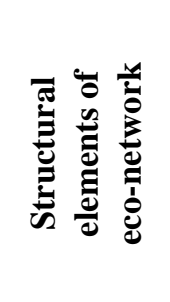 } & \multirow[b]{2}{*}{ 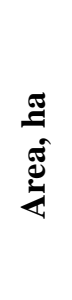 } & \multicolumn{5}{|c|}{$\begin{array}{l}\text { including due to the functional } \\
\text { zones of the NNP }\end{array}$} \\
\hline & & 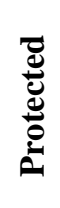 & 鰙 & 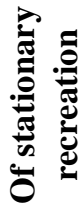 & 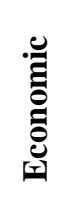 & 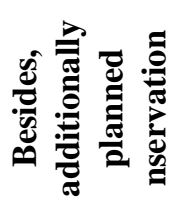 \\
\hline Key areas & $\begin{array}{c}208 . \\
5\end{array}$ & 0.3 & $\begin{array}{c}13.8 \\
7\end{array}$ & - & 43.7 & 150.63 \\
\hline $\begin{array}{l}\text { Connective } \\
\text { territories }\end{array}$ & $\begin{array}{c}81.4 \\
6\end{array}$ & - & $\begin{array}{c}81.4 \\
6\end{array}$ & - & - & - \\
\hline $\begin{array}{l}\text { Buffer } \\
\text { zones }\end{array}$ & $\begin{array}{c}311 . \\
20\end{array}$ & - & 3.08 & - & $\begin{array}{c}307 . \\
40\end{array}$ & - \\
\hline $\begin{array}{l}\text { Recreative } \\
\text { territories }\end{array}$ & $\begin{array}{c}219 . \\
73\end{array}$ & - & - & - & $\begin{array}{c}219 . \\
73\end{array}$ & - \\
\hline Altogether & $\begin{array}{c}820 . \\
89\end{array}$ & 0.3 & $\begin{array}{c}99.1 \\
3\end{array}$ & - & $\begin{array}{c}570 . \\
83\end{array}$ & 150.63 \\
\hline
\end{tabular}

An important component of the technology of planning works in Ukraine is the obligation of electronic documentation to be subsequently submitted to the State Land Cadastre [9] (Table- IV).

Table- IV: Information on structural elements of the eco-network that are included in the State Land Cadastre (only for key areas)

\begin{tabular}{|l|l|}
\hline Registered number & $\begin{array}{l}\text { near Kavetchyna village, Kamianets-Podilskii district, } \\
\text { Khmelnytsk region }\end{array}$ \\
\hline Location (administrative territorial unit) & Legend: \\
from A to 5 - the lands of Kavetchyna village \\
from 5 to B - the lands of NNP Podilski Tovtry, buffer \\
zone \\
from B to $\Gamma$ - the lands of citizen A. Ivanov, buffer zone \\
from $\Gamma$ to Д - reserve lands, \\
buffer zone \\
from Д to E - the lands of NNP Podilski Tovtry, buffer \\
zone \\
from E to $€$ - the lands of citizen A. Petrov, buffer zone \\
from $€$ to Ж - the lands of NNP Podilski Tovtry, \\
connective territory \\
from Ж to 3 - Dnister river \\
from 3 to A - reserve lands, connective territory \\
Scale $1: 25,000$
\end{tabular}

\begin{tabular}{|l|c|}
\hline Area, hectares & 63.6 \\
\hline Dimensions of lines around the perimeter & 7751 \\
\hline Coordinates of measured points & $\mathrm{X}=52174$ \\
\hline $\begin{array}{l}\text { Data on the fixation of the measured points to the points } \\
\text { of the state control network specifying witness marks }\end{array}$ &
\end{tabular}




\begin{tabular}{|l|c|}
\hline No data on land quality and judgment (forest land) & \\
\hline Information about other objects of the State Land \\
Cadastre, which territorially (in whole or in part) \\
includes the structural element of the eco-network of the \\
NNP Rodilski Tovtry. & \\
\hline Category of lands & lands of nature-reserved purpose \\
\hline Compound of lands & Wooded lands \\
\hline
\end{tabular}

\begin{tabular}{|c|c|}
\hline \multirow[t]{2}{*}{ Information on land use restrictions } & $\begin{array}{l}\text { It is forbidden: } \\
\text { - special use (acquisition, collection) of the Red Book of } \\
\text { Ukraine objects for profit; } \\
\text { - general use of natural plant resources in case of their } \\
\text { deterioration, sharp decrease of population and cenotic } \\
\text { diversity; } \\
\text { - trade of medicinal and ornamental plant species and their } \\
\text { parts (roots, stems, fruits etc.) collected in order of common } \\
\text { use of natural plant resources; } \\
\text { - construction, launching of enterprises, constructions and } \\
\text { other objects and application of technologies that cause } \\
\text { disturbance of the conditions of habitat of flora objects, } \\
\text { littering, as well as contamination with chemical and other } \\
\text { toxic substances of the territories occupied by them; burning of } \\
\text { dry natural vegetation or its debris without the permission of } \\
\text { the state control agencies in the field of environmental } \\
\text { protection; }\end{array}$ \\
\hline & $\begin{array}{l}\text { - any activity that breaks natural processes which take place in } \\
\text { the natural complexes; } \\
\text { - any activity that is not connected with the tasks assigned to } \\
\text { them and threatens to conserve flora collections; } \\
\text { - use of aboveground (using helicopters) methods of treating } \\
\text { plants with toxic chemicals and herbicides; }\end{array}$ \\
\hline Normative monetary valuation, UAH & $804,311.04$ \\
\hline $\begin{array}{l}\text { Information on the documentation of the planning on } \\
\text { which the information is based }\end{array}$ & $\begin{array}{l}\text { Planning project for the organization of the territory of the } \\
\text { structural elements of the eco-network, State Enterprise } \\
\text { Khmelnitsky Research and Design Institute of Land } \\
\text { Management, } 2015 \\
\text { Instruction of Approval No. } 3256 \text { of June } 17,2015\end{array}$ \\
\hline The information is accepted by: & $\begin{array}{l}\text { Office of the State Geocadastre in Kamianets-Podilskyi } \\
\text { district, Khmelnytsk region the name of its territorial agency }\end{array}$ \\
\hline
\end{tabular}

The following information is added to the State Land Cadastre [10]:

1) registered number; 2) location; 3 ) the description of the boundaries with mentioning of adjacent structural elements of the eco-network; 4) area; 5) dimensions of lines around the perimeter; 6) coordinates of measured points; 7) data on the fixation of the measured points to the points of the state control network specifying witness marks; 8) data on land quality and judgment; 9) information about other objects of the State Land Cadastre, which territorially (in whole or in part) includes the structural element of the eco-network; 10) lands category on the territory of structural elements of eco-network; 11) compound of lands; 12) information about the restriction of usage of lands on the territory of structural elements of eco-network; 13) normative monetary valuation of the lands on the territory of the structural elements of eco-network: - value of normative monetary valuation; - date of normative monetary valuation; 14) information on the documentation of the planning on which the information is based: - name and date of the developing of documentation on land management, information about its developers; - name, date and number of the decision approving the planning documentation, the name of the agency that accepted it, and electronic copies of the relevant documents.

The information on land use restrictions within the territory of the structural elements of the eco-network is given to the State Land Cadastre too [10].

Sustaining ecological integrity is just one of several environmental goals of land use that fulfills other tasks related to sustainable development, poverty reduction, social justice and others. Assessment of the adequacy of the structure of nature conservation land use is given in TableV. 
Table- V: Evaluation of ecological representativeness of the land structure within the territory of Sokil village council when designing structural elements of the ecological network

\begin{tabular}{|l|l|l|l|}
\hline $\begin{array}{l}\text { Valuation } \\
\text { type }\end{array}$ & $\begin{array}{l}\text { At the } \\
\text { moment } \\
\text { of project } \\
\text { developmen } \\
\text { t, \% }\end{array}$ & $\begin{array}{l}\text { After } \\
\text { project } \\
\text { developm } \\
\text { ent, \% }\end{array}$ & $\begin{array}{l}\text { Changes } \\
+,- \\
\%\end{array}$ \\
\hline $\begin{array}{l}\text { Territory } \\
\text { plowing up }\end{array}$ & 59.7 & 55.9 & -3.8 \\
\hline $\begin{array}{l}\text { Territory } \\
\text { forestry }\end{array}$ & 6.1 & 6.1 & - \\
\hline $\begin{array}{l}\text { Unit weight of } \\
\text { ecologically } \\
\text { stable lands }\end{array}$ & 40.3 & 44.1 & +3.8 \\
\hline $\begin{array}{l}\text { Unit weight of } \\
\text { the } \\
\text { natural-reserv } \\
\text { ed fund lands }\end{array}$ & 6.5 & & \\
\hline
\end{tabular}

As it is shown in Table- $\mathrm{V}$, as a result of project changes in the structure of land, the ecological representativeness of the structure of environmental land use is improving, which is a positive aspect in the evaluation of the territory. Evaluation of the effectiveness of management of environmental land use is related to the legitimate creation (planning) of boundaries of territories of structural elements of the eco-network, information on land rights and other natural resources and territorial restrictions (burdens) in the use of land and other natural resources within their boundaries, etc.

In the process of planning in the appropriate methodological order, the institutional actions are made in terms of:

- the prediction, planning and organization of territories of ecological frame (as the structural elements of eco-network) of the system of rational use and preservation of lands at the regional, local and economic level;

- the ranging afield and surface marking of the territories of natural-reserved fund and others intended for nature protection purposes, healthful, recreational and historical and cultural ones

- the organization of the territories of agricultural enterprises, institutions and organizations for the purpose of creation of spatial terms for eco-economic optimization of use and protection of farmlands; the improvement of the structure and arrangement of land, cultivation areas, rotation systems, cutting and pasture rotation.

- the development and implementation of the system actions on planning for the saving of natural landscapes, restoration and increase of soil fertility, recultivation of disturbed lands and earth mulching of unproductive lands, land protection from erosion, flooding, drying, landslides, secondary salination, acidification, waterlogging, consolidation, pollution by industrial wastes and chemicals, etc., conservation of degraded and low-productive lands, prevention of other negative phenomena;

Table- VI: Valuation of transformational changes in agricultural land use within the territory of Sokil village council

\begin{tabular}{|l|l|c|c|c|c|}
\hline No & \multicolumn{1}{|c|}{ Name of land } & $\begin{array}{c}\text { Area at the } \\
\text { moment of the } \\
\text { project } \\
\text { development, ha }\end{array}$ & $\begin{array}{c}\text { Normative } \\
\text { monetary } \\
\text { valuation, } \\
\text { USA }\end{array}$ & $\begin{array}{c}\text { Area after the } \\
\text { development of } \\
\text { the project, ha }\end{array}$ & $\begin{array}{c}\text { Normative } \\
\text { monetary } \\
\text { valuation, } \\
\text { USA }\end{array}$ \\
\hline 1 & Tillage & 1954.2 & 2383349.49 & 1830.95 & 2233033.34 \\
\hline 2 & Perennial plantings & 10.6 & 27809.84 & 10.60 & 27809.84 \\
\hline 3 & Hayfields & 201.0 & 81572.65 & 324.25 & 1198396.47 \\
\hline 4 & Pastures & 157.5 & 47852.46 & 157.5 & 47852.46 \\
\hline 5 & Agricultural land, total & 2323.3 & 2540584.44 & 2323.3 & 3507092.11 \\
\hline 6 & $\begin{array}{l}\text { Under ways and purlines } \\
\text { and courtyards }\end{array}$ & 43.8 & 1222296.96 & 43.8 & 1222296.96 \\
\hline & $\begin{array}{l}\text { Total amount of agricultural } \\
\text { lands }\end{array}$ & 2386.5 & 4304264.07 & 2386.4 & 541382.67 \\
\hline
\end{tabular}

- the organization of the territories of other enterprises, institutions and organizations to create the conditions of sustainable land use and setting of limits and burdens (land servitudes) in terms of the use and land conservation.

In the process of design changes, the structure of agricultural land use has changed as well as its value according to the normative monetary valuation (Table- VI).

As it is shown in Table- VI, the value of agricultural land use increased by 966,51 thousand USA or $22,45 \%$.

\section{CONCLUSION}

The planning projects on the formation of components of eco-network in the context of the territories of village councils will allow to ensure compliance with the limited mode of economic activity in the respective territories, taking into account the requirements for rational use and protection of land, preserving the natural diversity of landscapes, environmental protection, maintaining the ecological balance. However, the cost of land use is not decreasing, but rather increasing. 


\section{REFERENCES}

1. A. Tretiak, V. Tretiak, L. Hun'ko, U. Lobun'ko, The organization of land use structural elements of the ecological network locally Ukraine (Book style). Kyiv: State Enterprise Komprint, 2016.

2. The State Cadastre of territories and objects of the Nature Reserve Fund of Ukraine [Online]. Available: http://pzf.menr.gov.ua

3. The Law of Ukraine "On ecological network of Ukraine" of June 24, 2004 [Online]. Available: http://zakon3.rada.gov.ua/laws/show/1864-15

4. A.M. Tretiak, "Environmental network Ukraine in the context of conservation land: state and problems (Periodical style - Accepted for publication)", Kyiv: Interregional Publishing Centre Medinform, 2015, pp. 5-27.

5. A. Tretiak, Land Management in Ukraine: Theory, Methodology (Book style). Kyiv: 2013.

6. A. Tretiak, V. Tretiak, L. Hun'ko, Land Management Design: organization of land use structural elements Econet Ukraine locally (Book style). Part 4, Kherson: Oldi-plus, 2016.

7.

8. The project of territory planning of National Nature Park Podilski Tovtry of conservation, reproduction and recreational use of its natural complex and objects. Kyiv: State Organization "State Ecological Academy of Post-Graduated Education and Management", 2012, 4 vol., $1-480$ pp.

9. The Law of Ukraine "On the Nature Reserve Fund of Ukraine" of June 16, 1992 [Online]. Available: https://zakon.rada.gov.ua/laws/show/2456-12

10. On the approval of the Procedure for conducting of the State Land Cadastre (Cabinet of Ministers of Ukraine authorization of October 17, 2012, № 1051). Official Gazette of Ukraine, 2010, ed. № 89, on November 30, pp. 183.

11. The Law of Ukraine "On the State Land Cadastre" on July 7, 2011 [Online]. Available: https://zakon.rada.gov.ua/laws/show/3613-17

\section{AUTHORS PROFILE}

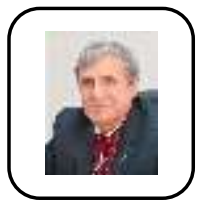

Anton Tretyak, Doctor of Economics, professor, corresponding Member of NAAS of Ukraine, honored worker of Agriculture. In 1973 he got his $\mathrm{PhD}$, in 1995 - a doctoral thesis. Since 1987 at the Chernivtsi branch of the Institute of Land Management of the UAAS as Chief Engineer, and since 1990 - Director. 1996-2000 - First Deputy Chairman of the State Committee of Ukraine for Land Resources, since 2001 - the vice-president of NAAS of Ukraine, 2006 - Academician-Secretary of the Department of Agrarian Economy and Land Relations of NAAS of Ukraine, 2008-2009 - First Deputy Chairman of the State Committee of Ukraine for Land Resources.

In 2000 he founded the Department of Land Management of the National Agrarian University, headed the Department of Land Management Design (2001-2007).

In 2010 created and headed the Educational and Scientific Institute of Economics and Ecology of Nature Management within the State Ecological Academy of Postgraduate Education and Management of the Ministry of Environmental Protection of Ukraine.

Areas of scientific work are the field of land relations, land use and protection, land management, land-use economics and land cadastre.

$\mathrm{He}$ is the author of more than 600 scientific works including the monographs - 51, 13 leaflets, legislative and regulatory acts - 68, educational manuals, textbooks - 21, author's certificates - 45, methodological and educational developments more than 90 .

Fields of interest: land administration, land market regulation, organization of agricultural enterprises lands, ecological and landscape land management, cadastre systems.

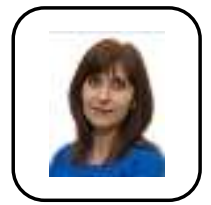

Liudmyla Hun'ko, Ph.D, Assoc. Prof.

Associate Professor of the Land-Use Planning Department.

In 1998 she has graduated from the National Agrarian University, majoring in land surveyor engineering.

In 2008, she has defended her Ph.D. thesis on the theme: "Ecological-landscape land management of agricultural enterprises in market conditions".

Participation in research works:

"Development of scientific bases of the economics of land use and land management";

"Development of methods of ecological-landscape land management of agricultural enterprises".

She worked at the central office of the State Agency of Land Resources of Ukraine. The civil service experience is 9 years.

Member of the Association "Land Union of Ukraine".

Special Qualifications:

- certified land surveyor engineer;

- the appraiser for the expert monetary valuation of land plots;

- land auctioneer.

She has published more than 70 scientific works, including 25 scientific works in professional journals. She has also tested the results of her research at various scientific conferences, symposia, seminars. For teaching and methodological support of the disciplines of the department, while working as an associate professor, 15 methodical recommendations, 8 scientific monographs, 5 manuals were developed and published, including two manuals with the MES of Ukraine stamp and one manual with the MAP of Ukraine.

Fields of interest: ecological and landscape land management, organization of agricultural enterprises lands, spatial planning of territories.

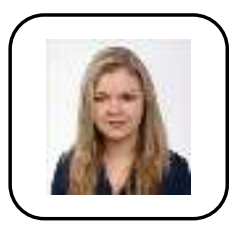

Nataliia Medynska, Ph.D, Assoc. Prof. In 2005 completed National Agricultural University with a degree in "Land Administration and Cadaster" and obtained the qualification: surveying engineer (diploma with honors).

In 2006 completed Master's course at pedagogical faculty with a degree in "Pedagogy of Higher School" and obtained the qualification: university professor (diploma with honors). Candidate of Economic Sciences from 2010 in the specialization 08.00.06 - Economics of Environmental Resources Management. 
Main stages of educational work:

From 2008 till 2011 - a Teaching Assistant of the department of Land Cadaster;

During 2011 - a Senior Lecturer of the department of Land Cadaster at National University of Life and Environmental Sciences of Ukraine;

From December, 2011 till now - an Associate Professor of the department of Land Cadaster at National University of Life and Environmental Sciences of Ukraine;

From 2014 till 2018 performed Dean's Deputy of Faculty of Land Management duties.

Fields of interest: land monetary valuation, the development of cadaster and registration system, development of real property.

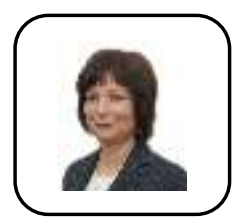

\section{Ivanna Hetmanchyk, Ph.D}

Associate Professor of the Department of Land Management Design of the National University of Life and Environmental Sciences of Ukraine.

In 1997 she graduated from Lviv State Agrarian University obtained a degree in Land Management. In 2010 she got her PhD thesis on the theme: "Ecological and economic principles of rational use and protection of lands of nature reserves", specialty "Economics of nature management and environmental protection.

Areas of scientific work are land relations, land use and protection, land management, land use economics.

She is the author of more than 65 scientific works, including 1 - textbook, 5 - monographs, 6 - textbooks, 26 - articles, 15 methodical and educational developments.

Fields of interest: organization of agricultural enterprises lands, ecological and landscape land management. 